\title{
Vitamin D deficiency and low osteocalcin concentrations in anorexia nervosa
}

\author{
V A FONSECA, V D'SOUZA, * SHARON HOULDER, M THOMAS, A WAKELING,* \\ P DANDONA
}

From the Departments of Chemical Pathology and Human Metabolism, and * Psychiatry, Royal Free Hospital and School of Medicine, London

SUMMARY The calcium, vitamin D, and osteocalcin concentrations were investigated in 17 patients with anorexia nervosa. Serum 25-hydroxyvitamin D (25 OHD) concentrations below normal were observed in $15(88 \%)$; only two patients has serum 1,25 dihydroxycholecalciferol $\left(1,25(\mathrm{OH})_{2} \mathrm{D}\right)$ concentrations below normal. Serum parathyroid hormone (PTH) concentration was also normal in all except these two patients. Serum osteocalcin concentration was below normal in seven of 14 patients.

Although a low concentration of serum 25 OHD is common in patients with anorexia nervosa in the United Kingdom, $1,25(\mathrm{OH})_{2} \mathrm{D}$ concentrations are usually normal. Hypovitaminosis $\mathrm{D}$ with secondary hyperparathyroidism is relatively uncommon. The subnormal osteocalcin concentrations observed in these patients probably reflect diminished osteoblastic activity, which may contribute to their osteopenia.

Two recent reports have shown that osteopenia occurs in patients with anorexia nervosa ${ }^{12}$ : both described patients with vertebral collapse, but claimed that vitamin D deficiency did not contribute to the pathogenesis of osteopenia. We also observed, in a separate study, that bone mineral index measured at distal radius was noticeably reduced in patients with anorexia nervosa. As some of the patients at our centre had low concentrations of 25 hydroxyvitamin D $(25$ OHD) we made a comprehensive investigation of the association between vitamin $\mathrm{D}$ and parathyroid hormone (PTH) in anorectic patients. We also investigated whether serum osteocalcin concentrations could be used as a marker of osteoblastic activity in the bone. To our knowledge, this is the first comprehensive study of vitamin D, PTH, and osteocalcin state and bone density in anorexia nervosa.

\section{Patients and methods}

Seventeen patients with anorexia nervosa, two male and 15 female, were included in this study. Their median age was 23 years (range 13-47). Their median body weight was $35 \mathrm{~kg}$ (range $24-51$ ), which was $65 \%$ of average body weight (range $42-90 \%$ ). The median duration of disease was two years $(0 \cdot 5-16)$. None of the patients had had pathological fractures. All patients except one had a daily calcium intake of less than $50 \mathrm{mg}$ daily, and a dietary vitamin D intake of less than 50 IU daily. One patient was taking regular supplements of vitamin D. All had plasma urea and creatinine concentrations within the normal range for our laboratory. Seventeen age and sex matched healthy volunteers were also studied as controls. All controls had body weights within $10 \%$ of the average body weight appropriate for height (Geigy Scientific Tables).

A fasting venous blood sample was collected from each patient without stasis. Blood was allowed to clot and centrifuged immediately at $4^{\circ} \mathrm{C}$. Serum was aliquoted and stored a $-20^{\circ} \mathrm{C}$ for PTH, $25 \mathrm{OHD}$, and $1,25(\mathrm{OH})_{2} \mathrm{D}$ assays. Plasma calcium and albumin concentrations, and phosphate, and alkaline phosphatase activities were measured by a SMAC Technicon autoanalyser (Technicon, Baskingstoke, UK).

Serum 25 OHD was measured by the method described by Preece et $\mathrm{l}^{3}$ and PTH was measured by a radioimmunoassay with an antibody directed against the mid molecular fragment of PTH as described by Roos et al ${ }^{4} ; 17 \beta$ estradiol was measured by a double antibody radioimmunoassay. $1,25(\mathrm{OH})_{2} \mathrm{D}$ was measured by the method described by Reinhardt $e t$ al. ${ }^{5}$ Serum osteocalcin was measured by radioimmunoassay in 14 patients by a method adapted from Price $e t$ 
$a l .{ }^{6}$ The osteocalcin antiserum reacts with both carboxylated and non-carboxylated forms of this protein. Reagents for assays of PTH, $1,25(\mathrm{OH})_{2} \mathrm{D}$, and osteocalcin were obtained from Immunonuclear Corporation, Stillwater, USA. The sensitivity and the

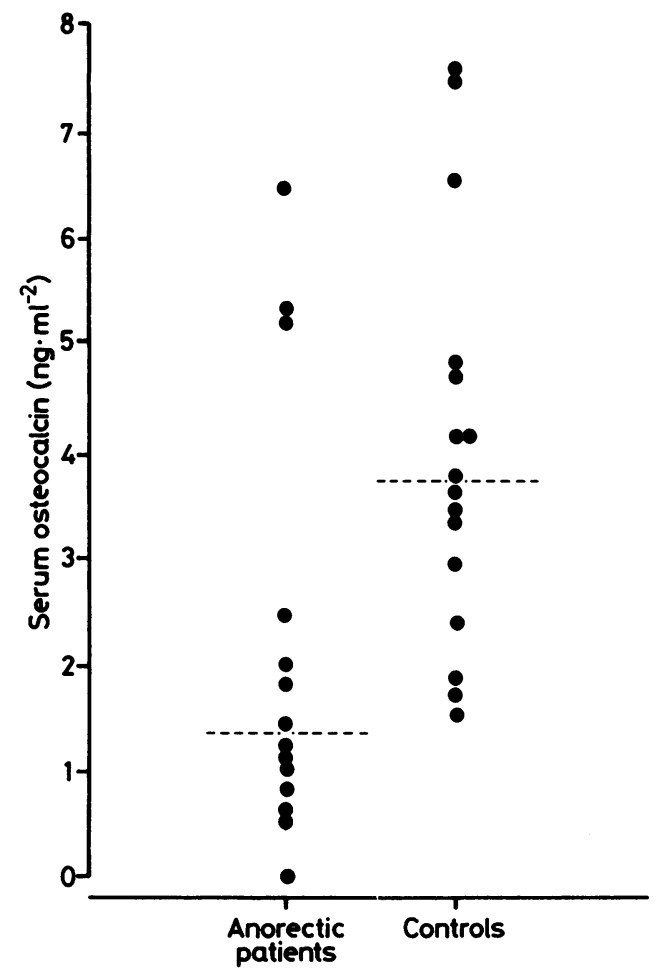

Figure Serum osteocalcin concentrations in patients with anorexia nervosa and controls. Dotted lines show median values $(p<0.01)$.

Table Biochemical features of patients investigated (figures shown are median and (range))

\begin{tabular}{|c|c|c|}
\hline & $\begin{array}{l}\text { Patients with } \\
\text { anorexia nervosa }\end{array}$ & Controls \\
\hline $\begin{array}{l}\text { Calcium }(\mathrm{mmol} / \mathrm{l}) \\
\text { corrected for albumin } \\
\text { Phosphate (mmol/l) }\end{array}$ & $\begin{array}{l}2 \cdot 33 \\
(2 \cdot 18-2 \cdot 49) \\
1 \cdot 05 \\
(0 \cdot 37-1 \cdot 35)\end{array}$ & $\begin{array}{l}2 \cdot 40 \\
(2 \cdot 1-2 \cdot 6) \\
1 \cdot 10 \\
(0 \cdot 7-1 \cdot 25)\end{array}$ \\
\hline \multicolumn{3}{|c|}{ Alkaline phosphatase (IU/l) 54} \\
\hline Albumin $(g / l)$ & $\begin{array}{l}43 \\
(35-47)\end{array}$ & $\begin{array}{l}40 \\
(30-50)\end{array}$ \\
\hline 25-OHD (nmol/l) & $\begin{array}{l}8^{*} \\
(<5-48)\end{array}$ & $\begin{array}{l}38 \\
(13-59)\end{array}$ \\
\hline $1,25(\mathrm{OH})_{2} \mathrm{D}(\mathrm{pmol} / \mathrm{l})$ & $\begin{array}{l}70 \cdot 5 \\
(20 \cdot 9-91 \cdot 7)\end{array}$ & $\begin{array}{l}70 \\
(40-120)\end{array}$ \\
\hline PTH (pmol/l) & $\begin{array}{l}63 \\
(21-124)\end{array}$ & $\begin{array}{l}58 \\
(25-85)\end{array}$ \\
\hline Estradiol $(\mathrm{pg} / \mathrm{ml})$ & $\begin{array}{l}15+ \\
(10-25)\end{array}$ & $\begin{array}{l}65 \\
(30-100)\end{array}$ \\
\hline Osteocalcin (ng/ml) & $\begin{array}{c}1 \cdot 4 t \\
(0-6 \cdot 5)\end{array}$ & $\begin{array}{l}4 \cdot 2 \\
(1 \cdot 5-7 \cdot 6)\end{array}$ \\
\hline
\end{tabular}

${ }^{*} \mathrm{p}<0.02 ; \mathrm{p}<0.001 ; \ddagger \mathrm{p}<0.01$ compared with controls. precision of these assays have been described previously. $^{78}$

Statistical analysis was carried out using the two tailed Mann-Whitney U test for non-parametric datas as the data were not normally distributed. Results areo expressed as medians and ranges.

\section{Results}

The median plasma calcium and magnesium concen trations and phosphate and alkaline phosphatase activities were similar to those in controls. None of the $\vec{\omega}$ patients had calcium or phosphate values belowe normal.

The median serum concentration of 25 OHD in $A$ patients with anorexia nervosa $(8 \mathrm{nmol} / \mathrm{l})$ was sig $\ddot{\text { i }}$ nificantly lower $(p<0.02)$ than that in healthy controls $(38 \mathrm{nmol} / \mathrm{l})$. Ninety five per cent confidencecr limits were less than $5-29 \mathrm{nmol} / \mathrm{l}$ in patients and $15-55 \circ$ $\mathrm{nmol} / \mathrm{l}$ in controls. Serum $1,25(\mathrm{OH})_{2} \mathrm{D}$ was low in twopatients who also had an extremely low 25-OHDT concentration. The median serum $1,25(\mathrm{OH})_{2} \mathrm{D}$ in the patients did not differ from those of controls. Serumo PTH was raised in both these patients with low 25 $\mathrm{OHD}$ and $1,25(\mathrm{OH})_{2} \mathrm{D}$. The median PTH concentra- $\overrightarrow{0}$ tion did not differ greatly between anorectics ando controls.

The prevalence of subnormal $(<1.8 \mathrm{ng} / \mathrm{ml})$ serum? osteocalcin concentration (seven of 14) was greater than that in healthy controls (one of $17 ; p<0.02$ ). Then median serum osteocalcin in the anorectic patients $(1 \cdot 4 \mathrm{D}$ $\mathrm{ng} / \mathrm{ml}$ ) was significantly lower than that in controls $(4.2 \mathrm{ng} / \mathrm{ml} ; \mathrm{p}<0.01)$. Ninety five per cent confidence? limits were $0-6.5 \mathrm{ng} / \mathrm{ml}$ in patients and $1.8-7.4 \mathrm{ng} / \mathrm{mb}$ in controls.

Serum oestradiol concentrations in patients with: anorexia nervosa were considerably lower than those in controls.

\section{Discussion}

The most important biochemical finding in our studyo was the significant decrease in osteocalcin concentra tions in patients with anorexia nervosa, and this is of? considerable interest. Osteocalcin is the major non collagen protein in the organic matrix of the bone. ${ }^{6}$ As it is synthesised by the osteoblast, it reflects the secretory activity of this cell. ${ }^{69}$ Low concentrations may therefore indicate diminished osteoblastico activity. As most of our patients had normals $1,25(\mathrm{OH})_{2} \mathrm{D}$ and PTH concentrations we canno attribute the low osteocalcin concentrations to? hypovitaminosis D or to changes in PTH. Low osteocalcin concentrations may be due to hypogonadal state. Notably, osteocalcin concentrations increase after the administration of oestrogenic and 
progestational compounds in menopausal women. ${ }^{10}$ Possible nutritional deficiency of vitamin $\mathrm{K}$ would also result in non-carboxyation of osteocalcin. ${ }^{6811}$

Our data also show that a large proportion (14 of 17 in our series) of patients with anorexia nervosa in the United Kingdom have concentrations of 25-OHD similar to those observed in vegetarians with osteomalacia in this country. ${ }^{12}$ Two patients from this group who had extremely low $25 \mathrm{OHD}$ concentrations also had subnormal $1,25(\mathrm{OH})_{2} \mathrm{D}$ and raised PTH concentrations. Thus most of these patients are able to compensate for their low $25 \mathrm{OHD}$ concentrations by maintaining adequate concentations of $1,25(\mathrm{OH})_{2} \mathrm{D}$. The normal concentrations of $1,25(\mathrm{OH})_{2} \mathrm{D}$ in association with low 25 OHD concentrations are even more impressive if one considers that these patients may have low concentrations of vitamin $D$ binding protein. This would explain why vitamin D deficiency is not often shown clinically in these patients. Clinical manifestations of hypovitaminosis D do, however, occur. We recently reported a case of anorexia nervosa with severe hypovitaminosis $\mathrm{D}$, hypocalcaemia, hypomagnasaemia, and myopathy. ${ }^{13}$ Apart from the occasional frank osteomalacia, vitamin D deficiency may also have contributed to osteopenia. In a preliminary study of Asian vegetarian patients we showed that osteopenia may occur in association with hypovitaminosis $D$ in the absence of secondary hyperparathyroidism. ${ }^{14}$ Marginal vitamin $\mathrm{D}$ deficiency contributing to osteoporosis has been described in the elderly. ${ }^{15}$

The absence of secondary hyperparathyrodism in most anorectic patients is also commensurate with normal plasma concentrations of calcium and 1,25DHCC. It is therefore noteworthy that the two patients with subnormal concentrations of $1,25(\mathrm{OH})_{2} \mathrm{D}$ and extremely low concentrations of 25 OHD had raised PTH concentrations. In a study on an inpatient geriatric population secondary hyperparathyroidism was observed only in those patients who had extremely low concentrations of both 25-OHD and $1,25(\mathrm{OH})_{2} \mathrm{D} .^{7}$ Osteocalcin concentrations in the geriatric population (largely female) were also low normal. ${ }^{?}$

In conclusion, although a large proportion of patients with anorexia nervosa in the United Kingdom have low concentrations of 25 OHD compared with those found in Asian vegetarians in this country, the concentrations of $1,25(\mathrm{OH})_{2} \mathrm{D}$ are normal in most. Those who have extremely low 25 OHD concentrations also have low $1,25(\mathrm{OH})_{2} \mathrm{D}$ concentrations and secondary hyperparathyroidism. This may contribute to the pathogenesis of osteopenia. Another mechanism underlying these patients' osteopenia is probably diminished osteoblastic activity, reflected in low osteocalcin concentrations. Whether osteocalcin concentrations and osteoblastic function can be stimulated with restoration of normal nutrition, regular menstrual cycles, or treatment with ovarian steroids remains to be seen.

\section{References}

1 Rigotti NA, Nussbaum SR, Herzog DB, Neer RM. Osteoporosis in women with anorexia nervosa. $N$ Engl J Med 1985;311:16016.

2 Szmukler GI, Brown SW, Parsons V, Darby A. Premature loss of bone in chronic anorexia nervosa. $\mathrm{Br}$ Med $J$ 1985;290:26-7.

3 Preece MA, O'Riordan JLH, Lawson DEM, Kodicek E. A competitive protein binding assay for 25-hydroxycholecalciferol and 25-hydroxyergocalciferol in serum. Cin Chim Acta 1974;54:235-42.

4 Roos BM, Lindall AW, Aron DC, et al. Detection and characterisation of small mid region parathyroid hormone fragments in normal and hyperparathyroid glands and sera by immunoextraction and region specific radioimmunoassay. $J$ Clin Endocrinol Metab 1980;53:709-21.

5 Reinhardt TA, Horst RL, Orf JW, Hollis BW. A microassay for 1,25-Dihydroxyvitamin $\mathrm{D}$ not requiring high performance liquid chromatography: application to clinical studies. $J$ Clin Endocrinol Metab 1984;58:91-7.

6 Price PA, Parthmore JC, Deftos LJ. New biochemical marker for bond metabolism: measurement by radioimmunoassay of bone GLA protein in plasma of normal subjects and patients with bone disease. J Clin Endocrinol Metab 1980;53:709-21.

7 Dandona P, Menon RK, Shenoy R, Houlder S, Thomas M, Mallinson WJW. Low calcitriol concentrations, secondary hyperparathyroidism and normal osteocalcin in elderly patients. J Clin Endocrinol Metab 1986;63:459-62.

8 Menon RK, Gill DS, Thomas M, Kernoff PB, Dandona P. Impaired carboxylation of osteocalcin in warfarin treated patients. J Clin Endocrinol Metab 1987;59:87.

9 Slovik DM, Gundberg CM, Neer RM, Lia JB. Clinical evaluation of bone turnover by serum osteocalcin measurements in hospital setting. J Clin Endocrinol Metab 1984;58:228-38.

10 Christiansen C, Riis BJ, Nilas L, Rodbro P. Uncoupling of bone formation and resorption by combined oestrogen and progestagen therapy in postmenopausal osteoporosis. Lancet 1985;ii:800-2.

11 Fonseca V, Epstein O, Gill DS, Menon RK, Thomas M, McIntyre N, Dandona P. Hyperparathyroidism and low serum osteocalcin despite vitamin $\mathrm{D}$ replacement in primary biliary cirrhosis. J Clin Endocrinol Metab 1987;64:873-7.

12 Dandona P, Mohiuddin J, Freedman DB, Weerakoon J, Fonseca V, Healy T. Persistence of parathyroid hypersecretion after vitamin D therapy in Asian vegetarians. J Clin Endocrinol Metab 984;59:535-9.

13 Fonseca VA, Havard CWH. Electrolyte disturbances and cardiac failure with hypomagnesaemia in anorexia nervosa. $\mathrm{Br}$ Med $\mathrm{J}$ 1985;291:1680-2.

14 Fonseca VA, Agnew J, Dandona P. Secondary hyperparathyroidism and bone density. Br Med J 1985;290:555-6.

15 Parfitt AM, Gallagher JC, Heaney RP, Johnston CC, Neer R, Wheddon GD. Vitamin D and bone health in the elderly. Am J Clin Nutr 1982;36:1014-20.

Requests for reprints to: Dr P Dandona, Metabolic Unit, Department of Chemical Pathology and Human Metabolism, Royal Free Hospital, London NW3 2QG, England. 